DOI https://doi.org/10.30525/978-9934-26-039-1-17

\title{
МАГІЯ СЛОВА В УКРАЇНСЬКИХ ЗАМОВЛЯННЯХ
}

\author{
Швидка Н. В. \\ кандидат філологічних наук, дочент, \\ дочент кафедри украӥнської мови та літератури \\ Донбаського державного педагогічного університету \\ м. Слов'янськ, Донеиька область, Україна
}

Небезпідставно замовляння вважають витоками культури, у них виокремлюють елементи першоматерії людської присутності у світі. До слова наші далекі предки ставилися надзвичайно шанобливо, вони глибоко вірили, що необережно вимовлене слово може «накликати» біду i, навпаки, сказане в добру годину принесе успіх, благополуччя. Слово було настільки ж матеріальним, наскільки й інші дійсно реальні предмети, залучені до замовлянь [5, с. 23].

Деякі науковці акцентували на схожій схемі між замовляннями й найдавнішими міфами: «Дійство - новий стан - дійство, що враховує новий стан» $[8$, с. 450]. У низці магічних текстів, як і в багатьох замовляннях, наявне ототожнення космічного й людського: стать земля, кров - вода, очі - сонце, дух - вітер тощо. Відзначаючи прадавність замовлянь, дослідники, зокрема О. Міллер, доводили, що замовляння давніші за молитви. Не замовляння походять від молитов, а навпаки, усі найдавніші пісні молитовного змісту $\epsilon$ молитвами, перекладеними на пізнішу мову. Спочатку вони були замовляннями, що грунтувалися на впевненості в тому, що ними вороже буде обов'язково заговорене, а корисне приговорене [6, с. 84].

$\mathrm{y}$ первісному вигляді замовляння мали язичницькі ознаки, із запровадженням християнства язичницький молитвослов замовлянь поступово замінили іменами християнських святих. У нинішньому вигляді українські заговірні тексти істотно християнізовані, що зумовлено проблемою трансформації статусу особи в замовляннях. Звичайно такі замовляння транспоновані в молитву, під час якої людина просить (не закликає) Бога змилуватися й допомогти. Головною дійовою особою $є$ вже не людина, а Бог, який із власної волі може допомогти чи відмовити людині, яка з посередника перетворюється лише на прохача: «Земле земська, водо річкова, а на Землі світ, а в світі люди, великі й малі. Допоможи, Господи, ангела достать - забрать слід раби Божої (ім'я). Стиши, Господи, Землю й Небо, да стиши в моєму тілі й душі мій біль. Миколо Угодничку, донеси молитву мою до Бога» $[9$, с. 20]. 
Адресоване до них прохання нерідко артикульвано у формі жорсткої вимоги чи заборони, і таким виразним імперативом замовляння відрізняються від християнських молитов, що з'явилися значно пізніше замовлянь як жанру i, вочевидь, на їхньому підгрунті. Такі замовляння $\epsilon$ маркером іншого усвідомлення природи, людини, світу, а також причин, мотивів і наслідків світових процесів. Отже, і первісний текст замовлянь, що значно змінювався, поступово втрачав своє змістове навантаження, перетворювався на рудимент у власному, хоч зовсім видозміненому вигляді [9, с. 21].

Функції замовлянь власне прагматичні, утилітарні, засновані на вірі в силу магічної дії проголошуваного слова, їх промовляли для досягнення конкретного результату: вилікувати хворого, отримати взаємність у коханні, викликати дощ, відвернути град тощо. У багатьох замовляннях наявні елементи давніх язичницьких вірувань, відгомін тих часів, коли людина одухотворювала природу, поклонялася їй, зверталася за допомогою до небесних світил, води, землі як сил, здатних протидіяти лихові, хворобам, зцілити недугу. Таке звертання до потойбічних добрих або злих сил, різних явищ і предметів $є$ звичним для народної традиції. Місяць i зорі користувалися особливою пошаною, вони завжди викликали як жах, так і благоговіння, до них постійно зверталися, зокрема під час лікування. Наразі, до молодого місяця зверталися 3 надією отримати сприяння в лікуванні від туберкульозу, зубного болю, ревматизму й інших захворювань: «Молодиче, молодиче, чи був ти в старого, чи болять зуби у мертвого? Як у мертвого не болять, то так $i$ y (ім'я) не боліли і не щеміли, і закам'яніли» [3, с. 37]. Вважали, що поява на небі молодика автоматично підсилює магічну силу слова.

Як стверджує М. Новикова, «особливе значення в замовляннях має зв'язок місяця зі світом мертвим. У язичницькому космосі мертві - не «поза світом», а в «іншому світі» щодо живих, неперехідної межі між світами тут немає» [7, с. 201]. Періоди народження нового місяця вважали періодами активізації нечистої сили, саме вночі демонічні персонажі діють під світловою егідою місяця. Для них місяць - це те ж саме, що сонце для живих. Місяць - світило потойбіччя, власне й активізація демонічних сил відбувається залежно від того положення на небі, а особливо на «молодика», коли вони святкують народження свого світила. Зцілення могло відбуватися лише тоді, коли місяць був «молодим»: «Молодий молодиче! Тобі в сповні, мені в здоров ї. - Ссть у нас три ияарі: один небесний, другой - земний, а третій - у лісі. - Як зійдуиия вони землі межувать, тоді в народженого, молитвеного (ім'я) зуби заболять» [1, с. 2], «Молодиче, молодиче, чи був ти в старого, чи болять зуби у мертвого? Як у мертвого не болять, то так $і$ у (ім'я) не 
боліли $і$ не щеміли, $i$ закам'яніли» [3, с. 37]. Українці Житомирщини вважали: «Щоб гроші були - побачиш молодика, побрязкай в кишені, а ще й поплюй на копійку, та й у кишеню, щеб зав 'язувалося, як в'яжеться місяиь, щзоб гроші зав'язувались, прибували...» [4, с. 4]. Вони вірили, що на молодика гроші в борг не можна ні давати, ні брати.

Місяць - магічна астральна сила, повновладний «князь» нічного світу. У деяких замовляннях оприявлено його царственість: «Місящю молодий! Було вас три иарі: одін ияарь зємной, другой - нєбєсний, трєтій - водяной...» [2, с. 2]. У замовляннях слобожани місяць називають Володимиром, Аврамом, Адамом - узвичаєними для народної словесності поетичними порівняннями: «Місяџю-Адаме, ім'я тобі Авраме! Дай тіла на ті кості; а як не даси, то прийми мощі!» [3, с. 31]; «Молодий ти місящь, Володимир...» [3, с. 861]; «Місяще Адаме! Був на тім світі...» [3, с. 192].

В ієрархічній системі небесних світил особливого статусу надавали зорі. Звертаючись до неї, найчастіше просили забрати безсоння й дати сон: «Заря зарніиа, красная дівиия: заря раня, заря пізня, возьми мої крикливиі і мої сонливці, понеси у чисте поле, у темні ліса. Там вам не гуляти і розкошувати, новорожденному, хрищенному $i$ молитвянному младению (ім'я) спати» [3, с. 492] тощо.

Провідними персонажами, які допомагали подолати недуги, є Бог, Божа Матір, християнські святі, що засвідчує їх значний вплив. Замовлянням притаманний усталений порядок переліку цих образів залежно від ієрархічного статусу. Важливіші й вагоміші постаті з них згадують раніше: «Господи, милостивий, довготерпеливий, многомилостивий» [1, с. 186]; «Присвятая Богородиия, виликая помошниия, св. Миколай угодник, скорий поморник, святиї апостоли, станьте на помочі. Київські, Охтирські, Печерські, Святогорські, св. Митрофан Воронижський, великий помошнику. Матерь Божа двохручна, трехручна, поможсте, благословите од усякой болізні, от уроків. Ви вроки, урочища, витряні, водяні, супротивні, спитині, ззидині, мужищькі, хлоп'ячі й дівчачі, тут вам ни стояти, щирого серия ни тоншити, жовтої кости ни ломити, червоної крові ни пити. Христами забиваю, молитвами викликаю, визиваю с твоӥх плечей, с твоїх рук, с твоїх ніг, $c$ твоїх пальиів, с твоїх семи десяти су ставиів, с твоєї голови. Ідіть собі, вроки, врочииі, на очерета, на болота, на гнилі колоди, де й вітер не заходе, де й півні не співають, де й огні ни горять, ладани не курять, християнський глас не заходе. I во вікі віків. Амінь» [3, с. 35].

Аби вбезпечити, захистити людину від хвороби, у замовляннях іноді створюють такі ситуації, які навіть у нереальному світі не можна зреалізувати: «Місящь на небі, риба в воді, медвідь в лісі, комарь на криші. 
Як сї четирі братії вмісті сойдутся, тоді у молитвеного, хрещеного раба Божого (імя) будуть зуби боліти. Нехай вони заніміють, закаменіють, затвердіють на віки віків» [2, с. 2].

Отже, вербальна магія у світоглядних уявленнях українців посідала чільне місце. Можна констатувати, що чимало замовлянь марковані елементами давніх язичницьких вірувань. Їм притаманний відгомін тих часів, коли людина персоніфікувала природу, поклонялася їй, зверталася за допомогою до небесних світил, води, землі як до сил, здатних протидіяти лихові, хворобам, зцілити недугу. Трапляються звертання до потойбічних добрих чи злих сил, до небесних світил, птахів, трав, різних явищ і предметів. Чимало текстів замовлянь, зафіксованих на початку XXI ст., зазнали впливу християнства, у них наявні згадки про церковні атрибути, відповідні образи: Божа Мати, Ісус Христос, Миколай Угодник; багато з них містять молитовний вступ.

\section{Література:}

1. Бабенко В. Этнографический очерк народного быта Екатеринославского края. Екатеринославль: Типография Губернского Земства, 1905. $144 \mathrm{c}$.

2. Ветухов А. В. Заговоры, заклинания, обереги и другие виды народного врачевания, основанные на вере в силу слова: Из истории мысли /Варшава: Тип. учеб. округа, 1907. Вып. 1-2. 522, VII с.

3. Иванов В. В. Жизнь и творчество крестьян Харьковской губернии. Очерки по этнографии края. Харьков: Издание Харьковского Губернского Статистического Комитета, 1898. Т. 1. 1012 с.

4. Кравченко В. Звичаї в с. Забрідді та по інших недалеко від цього села місцевостях Житомирського повіту на Волині. Житомир, 1920. $160 \mathrm{c}$.

5. Крушевский Н. Заговоры как вид русской народной поэзии // Варшавские университетские известия. Варшава, 1876. № 3. С. 1-69.

6. Миллер А. Ф. Опыт исторического обозрения русской словесности, с хрестоматиею, расположенною по эпохам: От древнейших времен до татарщины. 2-е изд., перераб. и доп. СПб.: КукольЯснопольского, 1865. Ч. 1. Вып. 1. 407 с.

7. Новикова М. Прасвіт українських замовлянь // Українські замовляння. К.: Дніпро, 1993. С. 7-29.

8. Топоров В. Н. Заговоры и мифы // Мифы народов мира. Энциклопедия: в 2-х тт. М.: Сов. Энциклопедия, 1992. Т. 1. С. 450-452.

9. Ятченко В. Замовляння та їх значення для вивчення ментальності українців // Народна творчість та етнографія. 1996. № 1. С. 15-21. 